Online:

\title{
DOUNG PEOPLE FROM BOSNIA AND HERZEGOVINA IN NORWAY: MIGRATION, IDENTITY AND \\ ETHNICITY
}

Dragana Kovacevic

University of Oslo, E-Mail: dragana.kovacevic@ilos.uio.no

\section{Acknowledgments}

This paper has been presented at the Third International Conference on Nordic and Baltic Studies in Romania: European Networks: the Balkans, Scandinavia and the Baltic World in a Time of Crisis hosted by the Romanian Association for Baltic and Nordic Studies and Valahia University of Târgoviste, and sponsored by the Romanian National Research Council, May 25-27, 2012.

\begin{abstract}
:
The article focuses on young people originating from Bosnia and Herzegovina, permanently residing in Norway, who first came to Norway as children and conflict refugees in the 1990s. It investigates how they relate to their identity and origin, and how they discursively represent nationalism(s) and wars in the sending society. It also discusses their integration into Norwegian society and poses a question how ethnicity is contextualized in a receiving society in which it is generally socially desirable to express values of tolerance and respect for multiculturalism. Material from the interviews with young Bosnians and the participant observation of relevant events makes it possible to reflect on such phenomena as transnational belongings and the so-called long-distance nationalism, leading to the discussion about the contested claims of victimhood in the post- Yugoslav immigration context.
\end{abstract}

\section{Rezumat:}

Lucrarea se concentrează asupra tinerilor care provin din Bosnia și Herțegovina, cu reședința permanentă $\hat{\imath}$ Norvegia, care au venit $\hat{\imath}$ primul rând $\hat{\imath}$ această $t$ ară țară în calitate de copii și refugiați ai conflictelor din anii '90. Aceasta investighează modul în care aceştia se raportează la identitatea și originea lor, precum și felul $\hat{\imath}$ care reprezintă discursiv naționalismul (naționalismele) și războaiele din societatea din care provin. Este abordată, de asemenea, integrarea lor în societatea norvegiană și este observată modalitatea în care identitatea este contextualizată într-o societate primitoare in care acesta este $\hat{i n}$ general de dorit a fi exprimate $\hat{i}$ cadrul social valori de toleranță și de respect pentru 
multiculturalism. Materialul din interviurile cu tineri bosniaci și observația participativă a evenimentelor relevante permit să se reflecteze asupra unor fenomene cum ar fi identitățile transnaționale și așa-numitul naționalism de distanțe lungi, ceea ce aduce în discuţie postura disputată de victimă în contextul imigrației post-iugoslave.

Keywords: Ethnicity, Identity, Long-distance Nationalism and Migration

Thesnia and Herzegovina lasted from 1992-1995 and
caused the largest refugee crisis in Europe since the
Second World War. Bloody ethnic conflict and ethnic cleansing campaigns drove hundreds of thousands of people out of their homes and forced them to look for a refuge both within the borders of their country and abroad, in other countries that were willing to accept them, whether on temporary or permanent bases. Norway was one of the countries that offered protection to Bosnian refugees during the war and in its aftermath. What makes the case of Bosnian refugees in Norway particularly interesting is the fact that this country, unlike many others, very soon after their arrival included Bosnian war refugees in various integration programs and offered the majority of them the possibility to stay in the country permanently. ${ }^{1}$

According to different sources the total estimated number of people with Bosnian origin in Norway is around 15,000, and the majority of the Bosnians residing in Norway are of Bosnian Muslim (Bosniak) origin, but there are also some Bosnian Serbs, Bosnian Croats and people from mixed marriages who were often the ones who needed to seek refuge outside of the country of origin. Quite often the ones who are willing to identify and call themselves Bosnians ${ }^{2}$ are people of Bosniak and possibly mixed origin,

\footnotetext{
1 See Marko Valenta and Sabrina P. Ramet, The Bosnian Diaspora: Integration in Transnational Communities (Farnham, Surrey, England: Ashgate, 2011). This observation only holds water for those Bosnian refugees who arrived during the war and in its aftermath. Later Norwegian asylum politics was much stricter and less accepting: for example, refugees from the Kosovo conflict did not receive the same kind of treatment in 1998 and 1999 as people from Bosnia did earlier in the same decade, a majority of them was ordered to return to their country upon the end of the armed conflicts.

2 In Norwegian language, bosnier translates as Bosnian and bosniaker means Bosniak, but the terms are quite often mixed and confused in Norway. 
while in many cases Serbs and Croats from Bosnia see themselves as parts of Serbian and Croat community and avoid calling themselves "bosniere" in the Norwegian context according to a widespread understanding of the word in this context. However, in former Yugoslavia this term typically referred to geographical origin and it did not bear an ethnic overtone. Abroad the term is often associated and confused with the term Bosniak.

While the majority of Norwegian Bosnians is at least culturally Muslim (Bosniak), as well as some of the most stigmatized and popularly considered as "hard to integrate" groups whose affiliation to Islam is often popularly perceived as one of the main obstacles for integration, this seems not to be the case for the white European Bosniaks. According to both the results of numerous surveys and research projects and popular beliefs, Bosnians in Norway are among the most successfully integrated groups and a shiny example of "good immigrants" and citizens. According to Valenta and Strabac ${ }^{3}$, they have successfully redefined themselves from poor asylum seekers to successful citizens of Norway, thanks primarily to the official policy of Norway that had them scattered all around the country to settle. As previously noted, most of them had no difficulties in resolving their status, as they were accepted based on special care for refugees.

My research is designed in such way that it focuses on a particular "inter-generation" of people, namely a generation that some sources denote as "one-and-a-half" generation of immigrants. I am interested in identifications of young people who originate from the territory of Bosnia and Herzegovina and who were actually born back in that sending society ${ }^{4}$, however, they cannot truly be considered the first generation of immigrants, as they moved to Norway as minors, together with their parents. I found that this focus group makes for an especially interesting case to study such phenomena as integration, transnational belongings and the so-called long-distance nationalism. ${ }^{5}$ Being educated and socialized in the host society, this generation could be expected to express tolerance and respect for multiculturalism much more than their parents' generation might. However, they are refugees from a horrible war, and this along with

\footnotetext{
${ }^{3}$ Valenta and Ramet.

4 Thereby they technically cannot be denoted as second generation migrants.

5 Benedict R. Anderson, Long-Distance Nationalism: World Capitalism and the Rise of Identity Politics (Amsterdam: Centre for Asian Studies Amsterdam, 1992).
} 
the fact that they were exposed to their parents' opinions, attitudes and memories while growing up can potentially turn them into more or less long-distance nationalists who might repeat and revive the essentializing agendas transplanted from the sending society through their childhood homes. Also, although they are part of a group that is popularly considered as well integrated, they often are still aware of their "foreignness" and the fact that they are immigrants who, probably, as put by many of my informants, "can never be really Norwegian" which also could be one of the triggers for the long-distance nationalism and the fact that a vast number of the people I got to talk to consider Bosnia a "real home" although often they speak Norwegian much more advanced than Bosnian.

In addition to all these research dilemmas, for my study the important question in the post-Yugoslav context is what their relations to "other" ethnics from the same area are, whether problematic and conflictbearing interethnic relations from back home are reproduced in the new host society and how memory is used to reconstruct history. The discursive representations of the wars in former Yugoslavia will be examined in light of this extremely violent ethnically framed conflict, but also in relation to personal immigration experiences and growing up in Norway. A very significant percentage of young people in Norway born from Bosnian parents take up higher education. There can be found evidence of them scoring higher even than ethnic Norwegians in this regard ${ }^{6}$. For all these reasons, young, often highly educated and well integrated young Bosnians are an interesting focus group to reflect on ethnic identity and immigrant nationalism and the fact that, as put by Glick Schiller, in many instances, transmigrants are acting in ways that reinforce but reconfigure the institutions and nationalist ideologies of migrant-sending countries ${ }^{7}$.

This paper reflects on findings and experiences from my fieldwork in Oslo, and the method of participant observation is supplemented with in-depth interviews with so far ten young people, in order to investigate how individuals perform their identities. Fieldwork findings are followed up with narrative analyses of media and social media discourse that are in a crucial way connected to Bosnians in Norway. I engaged in participant observation of informal gatherings of young Bosnians, events of the youth

\footnotetext{
${ }^{6}$ see Valenta and Rammet, 88

7 N. Glick Schiller, Migration, Development, and Transnationalization: A Critical Stance (New York: Berghahn Books, 2010). 
Bosnian organization founded at the University of Oslo, as well as lectures at a course at the University of Oslo that deals with the break-up of Yugoslavia and it is regularly attended by young people originating from the region. I also used newspaper articles and online sources that I found relevant for my subject, and repeatedly visited online groups formed and commented by Bosnians living in Norway, related to a special and interesting case that I will write about in more details in one of the final paragraphs of this article: I will present and discuss reactions that followed the screening of a documentary about the Srebrenica genocide on Norwegian national TV channel in April 2011 and the victim-centered discourse as a rather important part of self-representation of this particular refugee group.

In the conclusion I will relate my hitherto collected findings with the theories about transnationalism and long distance nationalism, and proceed with the discussion of the possible hypotheses for the desirability of the victim image.

Besides integration patterns and the number of immigrants, reasons for focusing on people origination from this country in my research were numerous: it was the site of the most violent and destructive conflict of all the conflict sites in the former Yugoslavia. Importantly for this project and the discussion of long-distance nationalism, there are serious challenges to the maintenance of the unity of this country to this day, due especially to the tensions between two separate ethnically divided entities established by the 1995 Dayton Peace Agreement. Territorial unity is perceived as a constant challenge and a very special situation. ${ }^{8}$ The threat lies in the wish of presumably most of people in the Serbian entity to secede. A large number of the Bosnian Serbs themselves perceive the situation as unsolved as well, as Republika Srpska is not an independent state they strive towards. As an additional complication, when it comes to the Croats, the third largest ethnic group in this country, the more nationalist members of this community would either advocate for the existence of a separate Croatian entity as the third one, or, in the most extreme right nationalist

\footnotetext{
8 I would in future be interested to explore whether increased transnational engagements of a diaspora stand in direct correlation with an "unfinished" nature of a national political project. Arguably this contributes to patriotic feelings and engagements of the diaspora. For this a good comparison would be Tamil refugees all over the world today, but also the Zionist project prior to the establishment of the state of Israel.
} 
dreams, propagate a complete independency of "Herzeg-Bosna" 9 and even its union with Croatia.

For the part of this article based on interviews, opinions of young people who see themselves as non-nationalists (although some of them did clearly and openly declare as Bosnian patriots), are taken into consideration. ${ }^{10}$ They have university education and make high use of modern technologies in their everyday life and very much so for their transnational practices. In the course of the interview they typically exhibit a high level of awareness of what is seen as politically correct, and view nationalism (defined as chauvinism) as a bad thing.

The almost unanimous immediate answer to the question what homeland is was typically Bosnia and Herzegovina, however, patriotic discourse was appropriated so that it excludes nationalistic outbursts, hatred and open ethnic distance. Some expressions of the ethnic prejudice do come up, but often and typically mentioned when talking about how some others view things. ${ }^{11}$ That would seemingly go in line with Vertovec's claim that transnationalism leads to abandoning the myth of homogeneous and mono-cultural nation state. However, I would argue how in many cases transnational practices keep this myth alive and turn to be reaffirmations of ethnically based ideologies of a sending state.

A young woman I interviewed, one of the most actively engaged members of the Bosnian youth organization founded at the University of Oslo, stated how all the statistics show how well the Bosnians are integrated, but she continued by saying: "We have already proven that we are good Norwegians. Now let's try to at the same time be good Bosnians." She felt that Bosnian youth is so well integrated that they become easily assimilated (which is viewed as a negative development) and do not know

\footnotetext{
9 A highly charged name that Croatian far right uses to refer to what they see as Croatian Bosnia.

10 An important note for the future research and for reading of the results presented here is that by far the most numerous and influential Bosnian organization in Norway is the Islamic Union of Bosniaks in Norway, whose young member I still have not had the chance to talk to, but I do intend to do so. Because of the organizations presumably strong and exclusive religious and ethnic affiliations, it might very well be the case that opinions they would express are much less tolerant and politically correct than attitudes of young secular and liberal people I had the chance to talk to, but I cannot be sure of it at this stage of my research.

11 Often their parents or relatives.
} 
the basic things about the homeland.12 She repeatedly said how she was a proud Bosnian, but the term ethnicity had a very bad sound for her because of the ethnic war in Bosnia. Although she came from a Muslim family and saw herself as a believer (although not practicing Islam in a strict manner) she stated how she is a Bosnian, not a Bosniak. She disliked this latter term and found it exclusive and artificial. In her view, an Orthodox (Serbian) friend from her hometown is no less Bosnian than she is, both having a long line of ancestors in Bosnia. But she feels that often Bosnian Serbs refuse to accept Bosnia as their homeland, which is a shame ${ }^{13}$. The informant mentioned how her parents do not share her tolerant views and how she was often told "not ever to trust a Serb". She expressed understanding for their suspiciousness by mentioning a concrete example of her mother's friend whom they heard committed crimes against Bosniaks during the war. This friend contacted the informant's mother after the war and claimed those accusations were not true, but the mother did not believe it and remained convinced this is just one more example of why Muslims never should trust the Serbs again. The interviewee, however, stated how she does know and befriend people of Serbian and other Yugoslav ethnic backgrounds "here" in Norway. She was not the only informant to state that the parents are both less integrated and less open and tolerant then the young people are. The parents typically have less contact with the Norwegian host society, and faced with forced displacement they were challenged to renegotiate their identities in a much different way than their at the time underage children.

But a renegotiation of identities is constantly enacted, especially in the case of immigrants, and nationality can be recombined, concealed or displayed as it was put by Vertovec. ${ }^{14}$ People "under-communicate" what

\footnotetext{
12 She feels there are too many "too Norwegian" young Bosnians, they "dye their hair blonde, have only Norwegian friends". I so far have not run across an informant that could fit this description (possibly because of the snowballing method), except possibly one young girl scheduled to be interviewed in spring 2012, who comes from a mixed background. However, she also speaks perfect BCMS and I cannot be sure how she herself feels and identifies before talking to her.

13 An example of conflicting identities she mentioned was the tension between "Bosanci" and "Hercegovci", saying that conflicts and even violent fights happen between them in Norway. On her side, every time she mentioned Bosnia she would use the whole term Bosnia and Herzegovina. Consistent insistence on the full term clearly shows her desire for the unity and "wholeness" of her homeland.

14 Vertovec 2010, 12.
} 
they feel they need to and communicate what they choose to. Asked about whether they are in any way affected by public and media anti-Islamic discourse after 9/11, many people I talked to responded negatively, with more or less the same explanation: No one sees I am a Muslim. I talk like a Norwegian. I am white. I am not visibly Muslim. I never publicly display my religious affiliation. But people do insist on certain national identities when they decide it is time or place to do so: I don't want to be fully assimilated. I want to be a good Bosnian. I want to do something for Bosnia. I can never really be Norwegian. Bosnia and Herzegovina is my real homeland. I am proud to be a Bosnian ${ }^{15}$. Immigrants walk these lines while being aware of different cultures because they found themselves on the boundaries of it ${ }^{16}$. In this case, young immigrants calculate and negotiate the fact that they are able to blend in much more than some other immigrant groups. ${ }^{17}$

A very active and influential youth association was founded in 2007 by young Bosnians studying at the University of Oslo. As they say: "The aim of this association is, among other things, to create a bond between young Bosnians in Norway, strengthen the multicultural and multi-ethnical Bosnian identity, strengthen the bond between Bosnians in Norway and their native country, nurture the Bosnian tradition, customs, language and culture among Bosnians in Norway, strive for activity and motion among young Bosnians. "18 A number of the events they organized, although most often held in Oslo, dealt with political and social issues in the homeland. Their current main project is physically located in Bosnia ${ }^{19}$. Organization has an aim to raise awareness in diaspora about what is going on home and help them realize how they can help from their own position, as citizens of one of the richest countries in the world. They claim to be proud Bosnians and Herzegovinians although satisfied with life in Norway and trying to pick up the best of both cultures, in words of one of them, "open to the other, but taking care of your own". "Their own" is in this case ideally seen

15 These are not literal quotes of their words, but my own retelling of the pattern of their responds.

16 See T.H. Eriksen, Small Places, Large Issues: An Introduction to Social and Cultural Anthropology (London: Pluto Press, 2010).

17 One young Bosnian men said to me: "A regular Norwegian gets his or her picture from news about men with beard and women that are covered. It is about the way one looks." Gellner spoke of entropy resistant traits, distinguishing marks of the minority that cannot be removed whether the members wish so or not. (Eriksen 2010, 285.)

18 http://www.uio.no/english/student-life/societies/international/e_stecak.html

19 Free legal aid for people in one municipality in Bosnia, supported by Norwegian funds. 
as Bosnian without ethnic divisions. ${ }^{20}$ They feel like that being engaged to help the homeland is a socially responsible thing to do, and opting for complete "Norwegianness" and assimilation is something people involved in this project would pass a moral judgment on. Some of them feel like this kind of active engagement is a sort of a solution for their position between the two worlds. But they generally want to stay and live in Norway. ${ }^{21}$

Adrian Farwel noted how immigrants, who are between two or more cultures, are also good indicators of power to be found by playing on the line between belonging and non-belonging. Although being "a Bosnian in Norway, and a Norwegian in Bosnia" is a disruption and a tense and stressful existential position, it has its advantages in terms of networking and belonging. In line with that goes the fact that interviewees were typically happy and proud to claim that Bosnians are among the most integrated immigrant groups in Norway. More if them stated there is no such thing as a Bosnian ghetto in Oslo or any other city where they live grouped, in difference to some other groups of immigrants who do express that kind of behavior, and they considered the lack of that as a positive thing. They saw themselves as integrated and acculturated ${ }^{22}$, but still Bosnian and stating the need for the Bosnian community in Norway to be better organized and connected, in order to help the homeland. What is the social capital that they would expect out of it was not clearly stated, however, we may guess that is partly so because they feel they cannot be "really" Norwegian. As the majority has political power, that might explain the increased interest in a state where they are not a minority, which partly shows how essentializing views of national identities are still dominant in the everyday life of many people.

One of the interviewees claimed he was lucky because he grew up in a little town, surrounded by mostly Norwegian counterparts, so he learned the language easily and fluently. He thinks it is impediment to integration if you end up in a city like Oslo, and create such a ghetto where

\footnotetext{
20 Aftenposten, the largest Norwegian daily, published a centerpiece interview with three young leaders of Stećak 29 May 2011 and it was emphasized how they refuse to say which of the ethnic groups in Bosnia they themselves belong to, and refuse to ask the others about it, as they find it wrong and uncomfortable to do so.

21 "It (Bosnia and Herzegovina) will always be my homeland, but my home will be Norway." said one young man in the interview.

${ }^{22}$ Quite often it was obvious to me that they think in Norwegian and translate it into Bosnian as they speak, based on construction of certain sentences.
} 
only foreigners live. However, another informant stated she was exposed to racism and discrimination growing up in a little town, but not once she moved to Oslo. She claimed that because of the fact that she finished elementary school in a little town in Norway, high school in Bosnia and again university in Oslo, she had to face different kinds of discrimination ${ }^{23}$ : in her own words, she experienced the racism of Norwegian kids in the little town, but the help and care of teachers who tried to prevent that. In Bosnia, it was exactly the opposite. Her high school teachers were the ones targeting her (she felt) as someone who came back to Bosnia from Europe, making her ashamed she does not speak and read Bosnian well enough. After moving to Oslo to study, she claims not to have experienced any discrimination anymore.

It was often stated by my young informants how parents usually had plans and ideas of returning to Bosnia as soon as possible when they first came to Norway (perhaps due to their official status as permanent refugees at the time, but according to many testimonies, also due to their genuine wishes to go home), and often much longer than just during the first period, until they finally realized it might not be possible, due to many reasons and, not rarely, economic ones.24. Young and integrated people would typically see Norway as a more open and tolerant society than Bosnia and Herzegovina, which they perceive as a really good thing, and seem sorry or sometimes even embarrassed to state how their parents are much less open to differences than they are. One informant said how unlike him, parents socialize neither really with Norwegians, nor with the Balkan "others", or if and when so, only superficially and being extra careful not to mention anything possibly inflammatory and "nationally inclined", as he said, knowing in advance some others would strongly disagree. Such subjects are avoided in a direct personal contact. To illustrate the perception of a serious generational gap, during a seminar about position of women and youth in Bosnia organized by the youth organization I observed, that included panelists such as a minister and journalists from

\footnotetext{
23 Discrimination, of course, is one of the most serious impediments to a successful integration of a group.

${ }^{24}$ In only one of the cases did parents of an informant actually return, and that is in the aforementioned case of the young lady came back alone after five years of high school in Bosnia. 
Bosnia and the Bosnian ambassador in Norway, several older people turned the part of panel discussion open to questions from the audience into war stories and accusations. Young organizers were at first glad a lot of older generation Bosnians came (the comments I heard from them prior to the start of the seminar, while the audience was still arriving), but as the discussion turned to war and to expressions of intolerant views, they appeared to be, in later conversations with me, ashamed of that how "they" (the older ones) can never "let go": "You see? This always happens! They always end up talking this way", said one of the young organizers to me after the end of the formal part of the seminar.

The issue of what it means to be Bosnian, who "our" people and who the "others" are is even more complicated than earlier sketched. It is impossible not to consider multiple inter-ethnic tensions and war legacy. Many Bosnian organizations and individuals reacted strongly against a documentary about Srebrenica genocide shown in April 2011 on the Norwegian public TV station, NRK. The documentary was titled "Byen som kunne ofres" (City that could have been sacrificed). Dissatisfaction with this movie came out of the fact that indicated and implied that Bosniak wartime leadership holds a part of responsibility for the genocide in Srebrenica and the fact that the documentary continuously referred to the war crimes in Serbian villages surrounding Srebrenica prior to the actual genocide when Serbian army entered the city. This all provoked protests from numerous Bosnian and Bosniak organizations, including the youth organization I observed, in particular, at the Islamic Union of Bosniaks in Norway reactions in the social media and in the Bosnian Post magazine(a main printed medium of Bosnians in Scandinavia), and also the protest note by the Embassy of Bosnia and Herzegovina in Oslo. The most often repeated argument was that NRK falsifies the truth in an attempt to present victims as perpetrators. This victim centered discourse is of particularly interested in this paper, since it is used in a central way in all the three main ethnic discourses relating to the war Bosnia and Herzegovina, but also in wider Yugoslav context. ${ }^{25}$ In this case study it will

25 The central point of Serbian nationalistic discourse lies in the claims that Serbs are wrongfully accused by the Western media of being the main perpetrators. Central point of Kosovo Albanian nationalist discourse involves strong insistences on the victim position, as 
be discussed how such discourse is appropriated by many people from Bosnia who are settled in in Norway.

Two facebook groups ${ }^{26}$ I often visited in June and July 2011 to follow the discussions about this documentary are called: "'Byen som kunne ofres', najsonal skam for Norge" ('City that could have been sacrificed', a national shame for Norway) and "Bosniere mot NRK", (Bosnians against the NRK). Both groups have titles in Norwegian and posts are predominantly either in Norwegian or in Bosnian language. ${ }^{27}$ The main theme taken up by those leaving the posts was the unfairness and scandalous nature of this documentary, anger directed against the NRK and what the members often called the "Stoltenberg" 28 clan, perceived as pro-Serbian. The arrest of the general Ratko Mladic, the main culprit for the genocide in Srebrenica happened shortly after the screening of the documentary, in May 2011. This understandably ended up being the second most important topic in a lot of the posts and comments. Some members, especially in the second group, use very harsh language and even hate speech. Typically they were not censored and comments seemed not to be erased. However, I concluded that the main strategy behind these reactions is advocating for views of "the truth of what happened", mostly and interestingly in Norwegian, as often posts were in Norwegian and calling upon Norwegian people to realize who is right and who "the real victim" is, with a lot of concrete proposition for what could be done in order to achieve this.

This film provoked such strong reactions as it presumably jeopardized the desired and for a long time secured "victim" position.

\footnotetext{
it is in the Bosniak and Croat ones. These discourses are contested and completely mutually exclusive in the views of those who propagate such views.

${ }^{26}$ Of course not all of the members are young, but the administrators seem to be, as well as a lot of the members, whose statements I analyzed.

27 "Disse dokumentarene som er laget av NRK er ren serbisk propaganda og fulle av feil og løgn. Ove dokumentarce sto je napravila norveska drzavna televizija je cista srpska propaganda i puni su gresaka i srpski lazi!!!!!!!!!!» Translation : These documentaries made by NRK are a pure Serbian propaganda and full of mistakes and (Serbian) lies https:/ / www.facebook.com/pages/Bosniere-mot-NRK-Svi-sto-smo-protiv-NRKalle-somer-imot-NRK/198429010194447 Accessed 09.10.2011.

28 The current prime minister of Norway, Jens Stoltenberg, is the son of famous Torvald Stoltenberg who was one of the mediators and negotiators during the wars in former Yugoslavia. Certain discourses present him as pro Serbian and anti-muslim, due partly to the fact that he lived in Belgrade and served as an ambassador of Norway during the times of Tito's Yugoslavia.
}

80 
Being produced and shown on the public national TV station in Norway, the possible influence and perception of it was judged as serious and dangerous. Language and arguments used in the official reactions of organizations such as Stećak was of course much more correct and rational than the ones expressed by some individuals leaving posts on Facebook groups. However, that decent discourse, as mentioned, also explicitly complained about the confusion between who a victim and who a perpetrator is, in such a way that it identified these roles with ethnic groups.

One of the post reads: "I invite all the citizens of Bosnia and Herzegovina who live in Norway, who have survived Serbian torture and lost their dearest ones, to create a front and sue the serbs and the so-called serb republic (I intentionally write with small letters) and ask for war reparations. The main purpose is not money, it is the evidence of their crimes. Then let's see if NRK will support us..." 29

And another one says:

"This is a shame that a national TV from a country that accepted so many Bosnian refugees shows such lies, haven't they so far realized who the serbs are and what they are capable of doing. Shame." 30

In important ways the analysis of reactions to this documentary provided the possible hypothesis for one of the main questions I posed in the proposal for my overall research: Why are "branding" and a positive national image so important to the individuals who feel they belong to a certain nation, and what discursive strategies are used in order to achieve this goal? As immigrants, subjects are frequently tagged as "foreigners;" therefore, references to their ethnic origins are directly connected with their self-image. In this sense, "othering" may rather be a byproduct of building a positive group image, than of self-definition of "groupness" against the relevant others. The battle over "who is right" is partly related to having a more positive group image within the host culture, especially in cultures where ideas of human rights, tolerance, democracy etc. are

\footnotetext{
${ }^{29}$ Original in Bosnian: “Pozivam sve gradjane BiH koji zive u Norveskoj, koji su preziveli srpsku torturu i izgubili svoje najmilije da stvorimo front i tuzimo srbe i takozvanu republiku srpsku (pisem namjerno malim slovima) i trazimo odstetu... Glavni cilj nije novac ali jeste dokaz njihovih zlocina. Pa da vidimo hoce li nas NRK podrzati..."

30 Ovo je sramota da jedna drzavna televizija iz zemlje koja je primila toliko izbjeglica iz Bosne i Hercegovine prikazuje ovakve lazi, zar dosad nisu shvatili ko su srbi i sta su u stanju uciniti. Sramota.
} 
considered to be held at a premium. Positive group image seems to be connected with the access to material and social capital, and access to "European-ness" and "Norwegian-ness" can be seen as a finite resource: only those who have been "victimized" in the past, have the right to these positions in Norwegian society.

\section{Conclusions}

Attitudes and engagements of young people included in this observation present an example of social and political engagement aimed at presenting one political and social agenda, reproducing beliefs and political goals, as well as identifications clearly derived and inherited from the Bosnian context. It involves engagement in a very special Norwegian situation and settings, but almost exclusively from the point of view of being a Bosnian. If a victim position is challenged and contested, too much ends up being at stake, identity-wise. Being one of the refugees that got a special treatment and a welcome into their new country possibly exactly because of them being perceived as victims, contestations of this position challenge both their group position and their individual identifications and worldviews. "Transmigrants are immigrants who live their lives across national borders, participating in the daily life and political processes of two or more national states" (Glick Schiller, 1997, p. 155).

As Hylland Erikssen wrote, the world of transmigrants encompasses more than one national structure, however, it may develop into a particular form of nationalism, long-distance nationalism or patriotism. "The fact of migration in an era of fast communication thus also paves the way for long-distance nationalism (Anderson 1992) whereby the political scene in a given territory may be partly shaped by the agency of migrants (Eriksen, 2010, p. 306) 31 . In this sense, more than being a challenge for essentializing identities, transnational belongings and practices end up reaffirming the essentializing identities and reproduce the homogenizing agendas of the sending society. Transnational practices are clearly influenced by transmigrant's feelings of belonging and often even crucially by ethnic identifications and belongings.

However, as migrants, according to Eriksen, live in the two worlds and switch between cultural codes, people often learn to express their

\footnotetext{
${ }^{31}$ He gives the example of Tamil refugees in Norway, saying how the main concern of many of them is not integration, but supporting the separatists movement in Sri Lanka.

82
} 
belongings and attitudes in accordance with the generally accepted cultural code of the host society in, at least in situations when they are personally and directly held accountable for their own words ${ }^{32}$. It is my view that in the context of Norway, patriotism is a highly acceptable sentiment, while fierce nationalism and the expression of inter-ethnic prejudice are not. This might influence the formulations and discourse as presented in this research, to the extent where it might be more appropriate to talk about long-distance patriotism than long-distance nationalism from the point of you of the subjects included in this study/observation. The reason for this is twofold: One, Bosnian identity is, at least declaratively, inclusive and non-ethnic, and the very choice of such identification, although in some cases it might be just a cover term for the promotion of Bosniak ethnic nationalism ${ }^{33}$, often genuinely stands for one's belief in the multicultural and multiethnic past and future of Bosnia.

\footnotetext{
32 Which might partly explain the harsh language used in the anonymity of an online context, although Facebook posts is not necessarily anonymous and often the names and pictures are genuine, it still seems that people generally express their prejudices much more open in such a setting than in an everyday conversations.

33 Especially in the migration context, as a lot of people in other countries do not really distinguish and understand Yugoslav differentiations between highly politically charged terms such as: Bosniak, Bosnian, Bosnian Muslim, and Muslim. For Norwegians and others Bosnian often stands for what Yugoslavs would call Bosnian or a Muslim; being aware of this fact, even a Bosniak immigrant of nationalistic convictions might still perpetuate and promote such identifications in accordance with a Bosniak nationalistic agenda, while a nationalistic Serb from Bosnia would typically make sure to explain that not all people in Bosnia are Bosniaks.
} 


\section{References}

Anderson, Benedict R. Long-Distance Nationalism: World Capitalism and the Rise of Identity Politics. Amsterdam: Centre for Asian Studies Amsterdam, 1992.

Brubaker, R. Ethnicity without Groups. Harvard University Press, 2004.

Eriksen, T.H. Ethnic Identity, National Identity, and Intergroup Conflict, The Significance of Personal Experiences. In Social Identity, Intergroup Conflict and Conflict Reduction. Eds. Richard D. Ashmot et al. Oxford University Press, 2001.

Eriksen, T.H. Ethnicity and Nationalism, London: Pluto Press, 2002.

Eriksen, T.H. "Nationalism and Internet." In Nations and Nationalism. 13, No. 1 (2007): 1-17.

Eriksen, T.H. Small Places, Large Issues: An Introduction to Social and Cultural Anthropology. London: Pluto Press, 2010.

Fairclough, N and Ruth Wodak. "Critical Discourse Analysis." In Discourse as Social Interaction. Ed. Teun Van Dijk. London: SAGE Publications, 1997.

Fuglerud, $\varnothing$. Life on the Outside. Tha Tamil Diaspora and Long Distance Nationalism. London: Pluto Press, 1999.

Glick Schiller, N. "From Immigrant to Transmigrant: Theorizing Transnational Migration," Anthropological Quaterly 68, No.1 (Jan. 1995): 4863

Glick Schiller, N. "The Situation of Transnational Studies." In Identities 4, No. 2 (1997): 155-166

Glick Schiller, N. et al.. Towards a Transnational Perspective on Migration. Race, Class, Ethnicity, and Nationalism Reconsidered. New York: The New York Academy of Sciences, 1992.

Glick Schiller, N. et al. Migration, Development, and Transnationalization: A Critical Stance. New York: Berghahn Books, 2010.

Grillo, R.D. "Transmigration and Cultural Diversity in the Construction of Europe", http://www.europadiversa.org/eng/pdf/ponencia_grillo_eng.doc (2000), accessed 14.02.2011.

Guarnizo,L.E. and Michael Peter Smith. "The Locations of Transnationalism" in Transnationalism from Below. Eds. Michael Peter Smith 
and Luis Eduardo Guarnizo. New Brunswick: Transaction Publishers, 1998.

Guiberno, Montserrat and John Rex. The Ethnicity Reader; Nationalism, Multiculturalism and Migration, Cambridge: Polity Press, 2010.

Kostoiu, A. "Modes of Minorities' Integration: Explaining Historical, Economic and Political Factors." Journal of Identity and Migration Studies 2, No. 2 (2008).

Valenta, Marko, and Sabrina P. Ramet. The Bosnian Diaspora: Integration in Transnational Communities. Farnham, Surrey, England: Ashgate, 2011.

Van Dijk, T.A. Communicating Racism. Ethnic Prejudice in Taught and Talk. Newbury Park: Sage Publications, 1987.

Vertovec, S. "Transnational Challenges to the 'New' Multiculturalism", paper presented to the ASA Conference held at the University of Sussex, 30 March - 2 April 2001.

Wodak, R. et al. The Discursive Construction of National Identity. Edinburgh: Edinburgh University Press, 1999. 